\title{
Phylogeographic Studies Depict the Role of Space and Time Scales of Plant Speciation in a Highly Diverse Neotropical Region
}

\section{Bárbara Simões Santos Leal, Clarisse Palma da Silva \& Fábio Pinheiro}

To cite this article: Bárbara Simões Santos Leal, Clarisse Palma da Silva \& Fábio Pinheiro (2016) Phylogeographic Studies Depict the Role of Space and Time Scales of Plant Speciation in a Highly Diverse Neotropical Region, Critical Reviews in Plant Sciences, 35:4, 215-230, DOI: 10.1080/07352689.2016.1254494

To link to this article: https://doi.org/10.1080/07352689.2016.1254494

\section{曲 Published online: 22 Nov 2016.}

\section{Submit your article to this journal $\llbracket$}

Џlll Article views: 208

View Crossmark data \lceil

Citing articles: 5 View citing articles 5 


\title{
Phylogeographic Studies Depict the Role of Space and Time Scales of Plant Speciation in a Highly Diverse Neotropical Region
}

\author{
Bárbara Simões Santos Leal ${ }^{a}$, Clarisse Palma da Silva ${ }^{a}$, and Fábio Pinheiro ${ }^{b}$ \\ aLaboratório de Ecologia Molecular, Programa de Pós-graduação em Ecologia e Biodiversidade, Departamento de Ecologia, Universidade \\ Estadual Paulista (UNESP), Rio Claro, SP, Brazil; ${ }^{b}$ Departamento de Biologia Vegetal, Instituto de Biologia, Universidade Estadual de Campinas, \\ Campinas, SP, Brazil
}

\begin{abstract}
Phylogeographic studies have merged different disciplines to explain speciation processes at both spatial and time scales. Although the number of phylogeographic extant studies has increased almost exponentially, few have been conducted in tropical countries, especially using plants. Plants are interesting models for such studies because their responses to different habitat conditions are reflected directly in the size and distribution of populations, enabling direct tests of alternative demographic scenarios. Here, we review phylogeographic studies using plant species occurring in different vegetation domains within Brazil, which has the greatest number of plant species in the world. Based on a detailed examination of 41 published articles, we synthesized the current knowledge and discussed the main processes driving the high levels of plant diversity within Brazilian domains. General patterns of diversification could be inferred due to the number of species studied, especially in the Cerrado and Atlantic Forest, the most intensively studied domains (34.1\% and $17.1 \%$ of the studies, respectively). Distinct vegetation types within both biomes were affected differently by the Pleistocene climatic oscillations. Edaphic conditions and geographical barriers (rivers and mountains) have also influenced the phylogeographical patterns of plants species from Amazonia and the Atlantic Forest. Other Brazilian domains, such as the Caatinga, Pantanal, and Pampas, have been studied to a lesser extent and no common phylogeographic pattern across species could be inferred. Issues regarding past connections between distinct domains also remain unclear, including those affecting the two main forest domains in South America. Future research on plant species will fill these information gaps, improving our understanding of the complex diversification processes affecting the South American biota.
\end{abstract}

\section{KEYWORDS}

biodiversity; microevolution; neotropics; phylogeography; population structure; species diversification

\section{Introduction}

Species distribution patterns in space and time are critical for understanding speciation processes (Sanmartín, 2012). Major evolutionary forces such as gene flow, genetic drift, and natural selection will be directly influenced by landscape elements, leading to different degrees of divergence among populations and incipient species. For example, geographic barriers would prevent gene exchange among conspecific populations, which in turn may increase their differentiation due to drift and natural selection associated with different environmental conditions. The action of gene flow, drift, and natural selection could be related to historical climatic oscillation events and past geologic processes that changed landscape features and, consequently, the demography of populations and species. For example, glacial cycles dramatically changed the distribution of vegetation domains in South
America (Clapperton, 1993), reducing gene exchange and increasing the effects of drift in fragmented populations. Thus, to find support for speciation models, such as the refugee theory (Haffer, 1969), the associations between past climatic oscillations and both the time and intensity of evolutionary forces involved in lineage diversification must be explored. According to Bennett and Provan (2008), researchers aiming to provide support for the refugee theory need to provide evidence of changes in population sizes; consequently, the time periods in which drift and gene exchange were affected by such demographic changes.

The role of geographic space and time in speciation has been intensively studied within the field of biogeography (Lomolino et al., 2010; Sanmartín, 2012). Scientific expeditions to tropical regions in the eighteenth century have yielded explanations of the evolution of floras in

CONTACT Dr. Clarisse Palma da Silva clarissepalma@yahoo.com.br; cpalma@rc.unesp.br E Laboratório de Ecologia Molecular, Programa de PG em Ecologia e Biodiversidade, Departamento de Ecologia, Universidade Estadual Paulista (UNESP), Rio Claro, SP 13506-900, Brazil.

Color versions of one or more of the figures in this article can be found online at www.tandfonline.com/bpts.

๑) 2016 Taylor \& Francis 
different continents, and interest in biogeography again increased in the 1950s, when the theory of continental drift was fully accepted (De Queiroz, 2005). The use of molecular markers to investigate geographical patterns of variation, from populations to higher taxa, enabled the reconstruction of the evolutionary history of various groups, especially those with a poor fossil record (Soltis et al., 2009). At the end of the 1980s, a new discipline emerged aiming to investigate the effects of time and geographic space on speciation events: phylogeography. In his seminal study, Avise et al. (1987) coined the term phylogeography in an attempt to provide direction to those interested in the geographic context of speciation events. Later, Avise (2000) provide the basic agenda of phylogeography, guiding population-level studies interested in speciation.

Phylogeographic studies have increasingly merged different disciplines to explain the history and formation of species at geographic and time scales. Initial studies mostly used molecular datasets, using DNA polymorphisms as the primary source of information to infer past demographic events and the existence of multiple lineages in different environments (Olsen and Schaal, 1999; Collevatti et al., 2003). The characterization of highly informative nuclear and plastid regions enabled the testing of alternative demographic scenarios in plant populations (i.e., Palma-Silva et al., 2009; Bonatelli et al., 2014, and others). The role of historical refuges in the diversification of lineages and species has been confirmed for several plant species (Ramos et al., 2007; Ribeiro et al., 2011). The inclusion of species distribution models greatly enhanced the potential to infer past demographic events (Collevatti et al., 2015). By retrieving the potential past distribution area, the results obtained independently from the models could be crosschecked with the molecular evidence of population expansion and/or bottlenecks (Collevatti et al., 2012a; Lima et al., 2014). Natural hybrid zones have also been the subject of phylogeographic studies, which have involved spatial distribution patterns, genetic composition of parental and hybrid plants, and reproductive isolation across species boundaries (Hewitt, 2001; LorenzLemke et al., 2006; Palma-Silva et al., 2011). Because species formation is a population-level process, the study of reproductive isolation within species may shed light on the processes operating during the earliest stages of speciation (Scopece et al., 2010). To achieve this, a detailed phylogeographic picture is crucial to understand how reproductive isolation evolves among lineages, in a geographic context (Pinheiro et al., 2013).

Phylogeography has been growing vigorously as an integrative discipline, bridging different sources of data (Diniz-Filho et al., 2008). The number of extant studies has increased almost exponentially (Beheregaray, 2008). However, until 2006, most studies were performed in the northern hemisphere, despite the fact that most biodiversity is concentrated in the tropics (Beheregaray, 2008). Indeed, Brazil is the 15th most-productive country in terms of phylogeography studies (Beheregaray, 2008), but has the greatest number of angiosperm species (BFG-The Brazil Flora Group, 2015). Therefore, few phylogeographic studies have been conducted in tropical countries with a rich biota, such as Brazil. There is also an imbalance between the number of studies of plants and animals. Turchetto-Zolet et al. (2013) reported that most phylogeographic studies in South America, across all vegetation domains of the continent, involved animals.

Various hypotheses regarding the origin of the considerable levels of plant diversity in tropical countries have been formulated (Antonelli and Sanmartin, 2011). Much effort has been devoted to investigating broad patterns of diversification, using plant phylogenies at higher taxonomic levels to determine the mechanisms of plant speciation (Hoorn et al., 2010; Hughes et al., 2013). In contrast, population-level studies have received less attention, and little is known of the microevolutionary mechanisms during the first stages of speciation. Here, we review phylogeographic studies of plant species in Brazil as biological models. Compared to other megadiverse countries, Brazil has the greatest number of angiosperms, with 32,086 species (BFG, 2015). Thus, using plant phylogeographic studies performed in Brazil, we discuss the main processes driving the diversification of lineages and species in this highly biodiverse region. Specifically, we had the following goals: (1) to review the current knowledge of plant phylogeography in Brazil; (2) to verify the occurrence of demographic processes (expansion and contraction) related to glacial/interglacial climatic oscillations; (3) to assess hypothesized refugia types (multiple or single); and (4) to discuss the role of geological and climatic changes during the Tertiary and Quaternary in shaping the phylogeographic patterns of plants in hyperdiverse vegetation domains in South America.

\section{Phylogeographic studies in Brazil}

This review focuses on the historical distribution and dynamics of Brazilian plant species based on phylogeography and the genetic signatures of vegetation history. For the purpose of this review, we consider all vegetation domains found in Brazilian territory. We review and compare studies on the open and seasonal vegetation domains known as Caatinga, Cerrado, and Pampas, and mesic domains such as the Brazilian Atlantic Forest, 
Amazon, and Pantanal. The literature survey was conducted in the Web of Science using the keywords "phylogeograph"” + "plant" and one of the following domains: "Amazon," "Atlantic Forest," "Caatinga," "Cerrado," "Pampas," and "Pantanal." Following this nonexhaustive survey, we selected 41 papers (Table 1) based on an inspection of their title, abstract, and keywords.

The first study using one of the reference phrases was published in 1999, and since then the number of studies has increased (Figure 1), albeit at a different rate than that for South America as a whole (Turcheto-Zolet et al., 2013). The studies involved 20 plant families and 30 genera. The four most studied families were Fabaceae (seven studies), Solanaceae (four), Orchidaceae (three), and Bignoniaceae (three) (Figure 2A). Approximately 78\% of the studies focused on only 11 families. Similarly, most genera were studied only once, whereas $30 \%$ were investigated twice or more (Table 1, Figure 2B). Most phylogeographic studies used trees $(53.7 \%)$ and herbs (36.6\%) as models (Table 1). Most studies (75.6\%) sampled species in only one phytogeographic domain (Figure 3 ). Cerrado was the most studied domain $(34.1 \%$ of the studies), followed by the Brazilian Atlantic Forest (17.1\%), Amazonia (14.6\%), Pampas (7.3\%), and Caatinga (2.4\%, one study). To the best of our knowledge, no phylogeographic study of plant species from the Pantanal domain has been published. Species occurring in more than one phytogeographic domain were the focus of 11 studies, most of which included populations distributed within the Cerrado domain. Species distributed across Caatinga and Cerrado were the most intensively studied (three studies), followed by the Brazilian Atlantic Forest and Cerrado (two), Amazonia and Cerrado (two), and the Brazilian Atlantic Forest and Amazonia (two). A comparative approach, using two or more co-distributed species, was used in only $17.1 \%$ of the studies. Niche models were included in ten studies, and hybridization events were detected in approximately one-third of the studies. Genic/intergenic DNA region sequencing was the most common method used in the phylogeographic studies in this review (Figure 4A). Microsatellite markers were used in nine studies, and in most cases were combined with sequence data. Eighteen studies combined nuclear and plastid regions, and the remaining used only nuclear (6 studies) or plastid markers (13 studies) (Figure 4B).

\section{Phylogeographic patterns in tropical forest domains}

The Brazilian Atlantic Forest and Amazonia are the two main forest domains in South America (Ab'Saber, 1977). The Brazilian Atlantic Forest is restricted to the Atlantic
Coast. Phylogeographic studies conducted in the Brazilian Atlantic Forest support the idea that this domain was deeply affected by historical climatic oscillation events, such as glacial/interglacial cycles, as well by geographic factors, such as mountains and rivers. The existence of multiple refuges, for example, is reported in almost all plant phylogeographic studies conducted in the Brazilian Atlantic Forest (Table 1). Palma-Silva et al. (2009) found multiple lineages along the distribution of Vriesea gigantea, an epiphyte bromeliad species distributed across the Brazilian Atlantic Forest. The different demographic signatures of northern and southern populations suggest regions in which the forest was fragmented (in the southern populations) and continuous (in the northern populations) during the Last Glacial Maximum (LGM), following the pattern expected for glacial refuges (Bennett and Provan, 2008). The same pattern has been reported for other plant species, including a tree species, Dalbergia nigra (Ribeiro et al., 2011) and a liana, Passiflora actinia (Teixeira et al., 2016). Contrasting results were provided by Pinheiro et al. (2011) using an herbaceous orchid species that occurs in sand dune vegetation close to the seashore. In this study, increasing levels of genetic diversity and signs of demographic stability were observed in populations distributed in the southern portion of the Brazilian Atlantic Forest. These results are in agreement with the notion that the Brazilian Atlantic Forest is a mosaic of different physiognomies, and each vegetation type was probably differently influenced by past climatic oscillations and geographic barriers (Leite et al., 2016). Considering this heterogeneous scenario, phylogeographic studies using species occurring in different environments may reveal novel and informative patterns.

The heterogeneous nature of the southern and northern regions of the Brazilian Atlantic Rainforest, as determined by floristic inventories (Oliveira-Filho and Fontes, 2000) and niche models (Carnaval and Moritz, 2008), has been confirmed by phylogeographic studies. Northern Rio de Janeiro, Espirito Santo, and southern Bahia are a transition zone between lineages, which show marked genetic divergences in this region (Ribeiro et al., 2011; Turchetto-Zolet et al., 2012; Pinheiro et al., 2013). The fragmentation of the Brazilian Atlantic Forest during glacial cycles, splitting these large portions of forest is a possible explanation for this pattern (Carnaval and Moritz, 2008). The existence of large river basins that act as geographic barriers for intraspecific gene exchange, such as the Doce River Basin, is an alternative explanation of the marked floristic differences between the northern and southern portions of the Brazilian Atlantic Forest (Bigarella et al., 1975; Prance, 1982). Recently, Cazé et al. (2016) provided evidence supporting the 


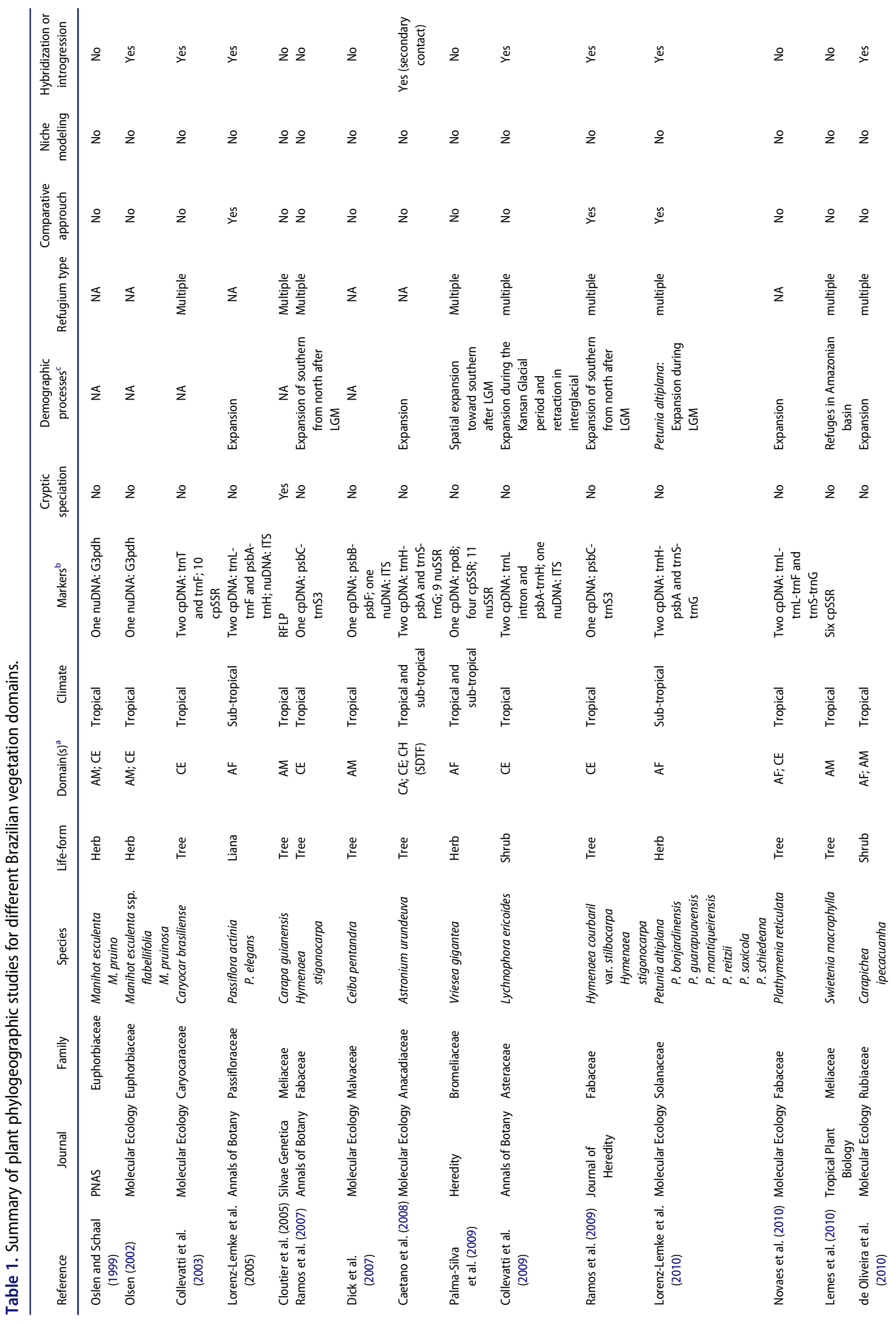




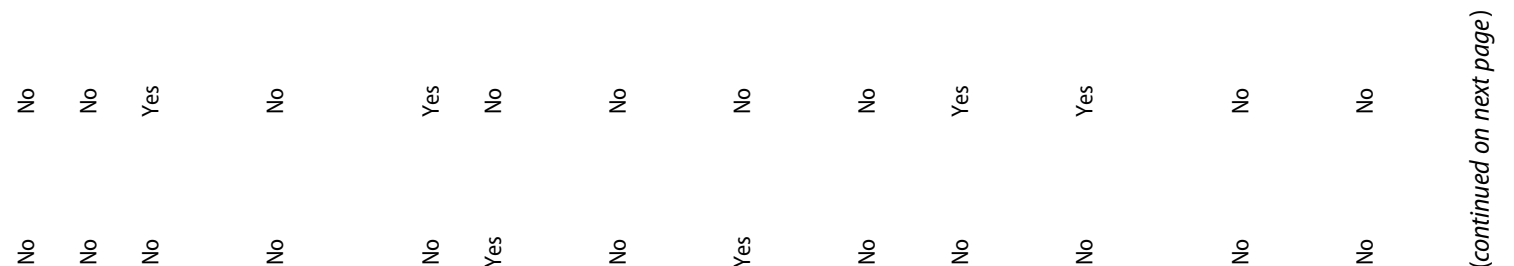

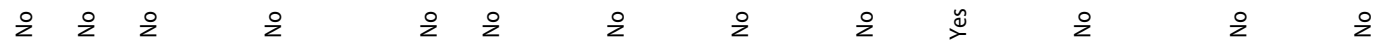

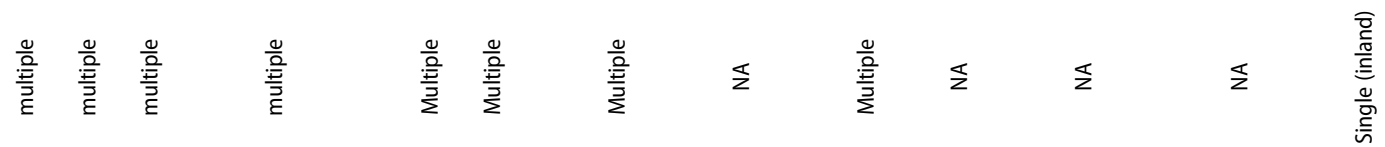

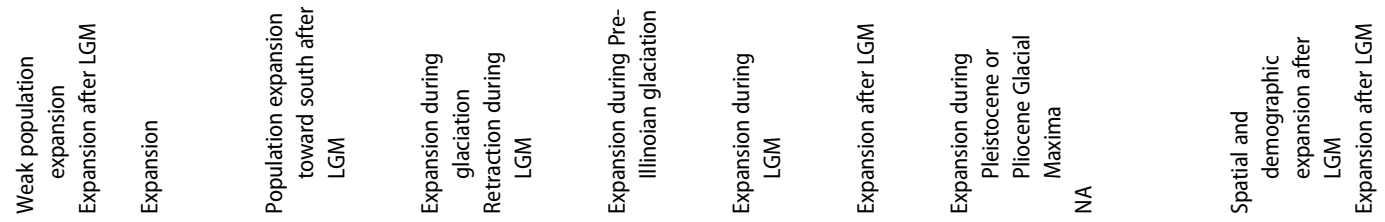

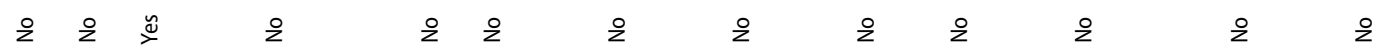

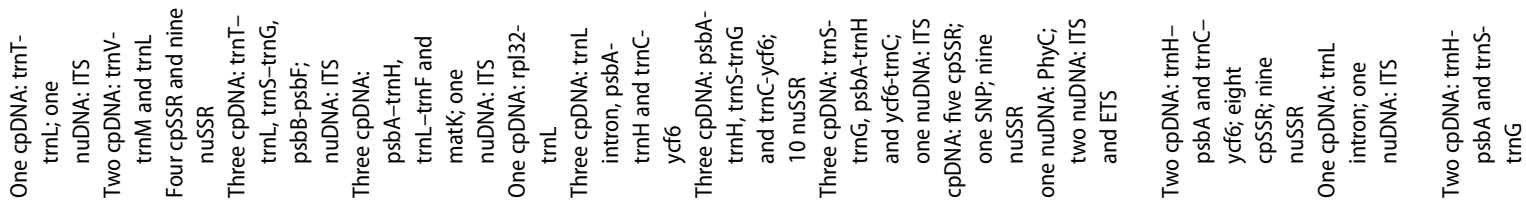

,

11

$\Rightarrow=\frac{1}{3}$

za

1

I)

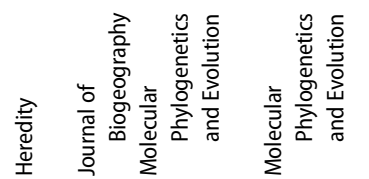

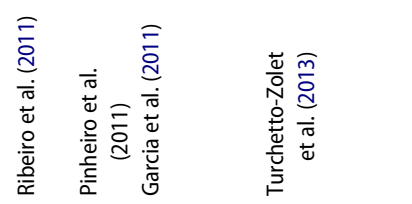

竞高

*

$\frac{0}{\overline{\underline{a}}}$

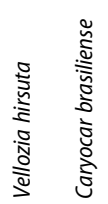

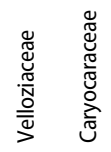

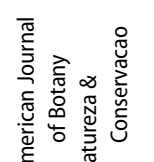

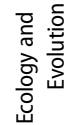

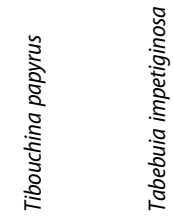

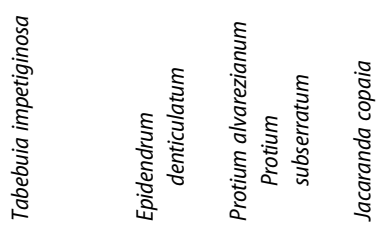

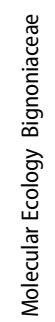

荧

宽

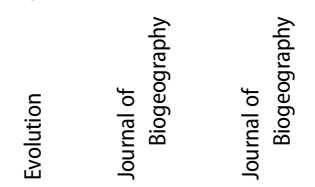

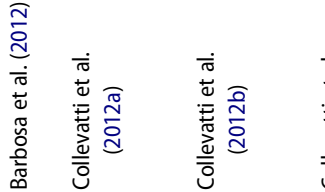

(1)


B. S. S. LEAL ET AL.

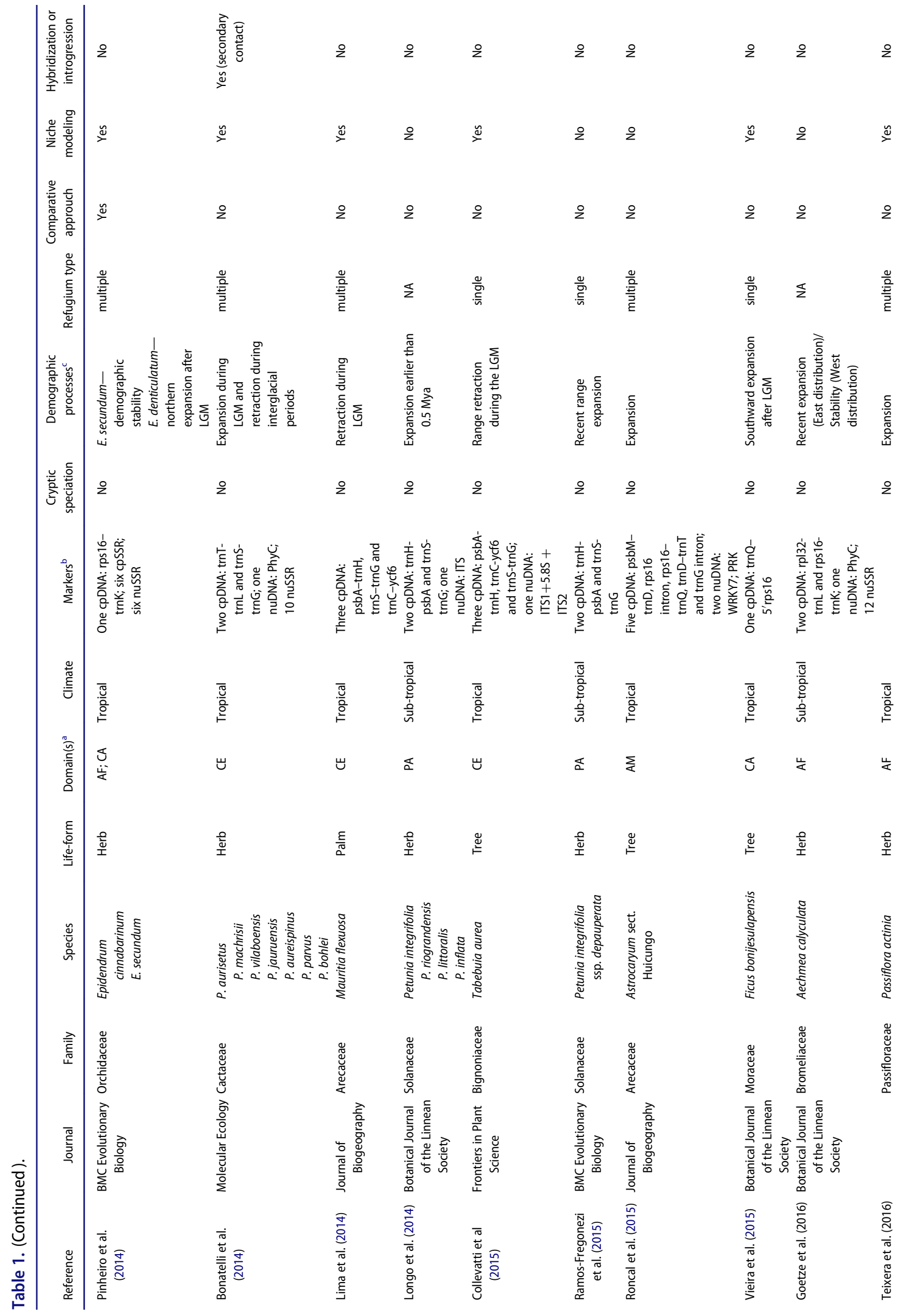


CRITICAL REVIEWS IN PLANT SCIENCES $\rightarrow 221$

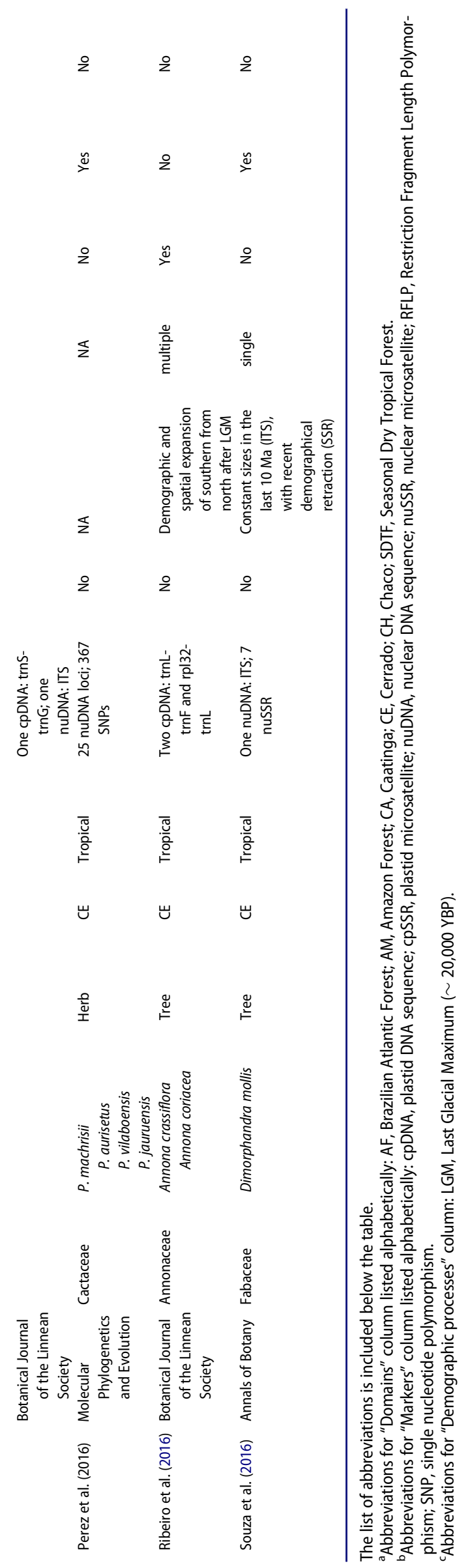




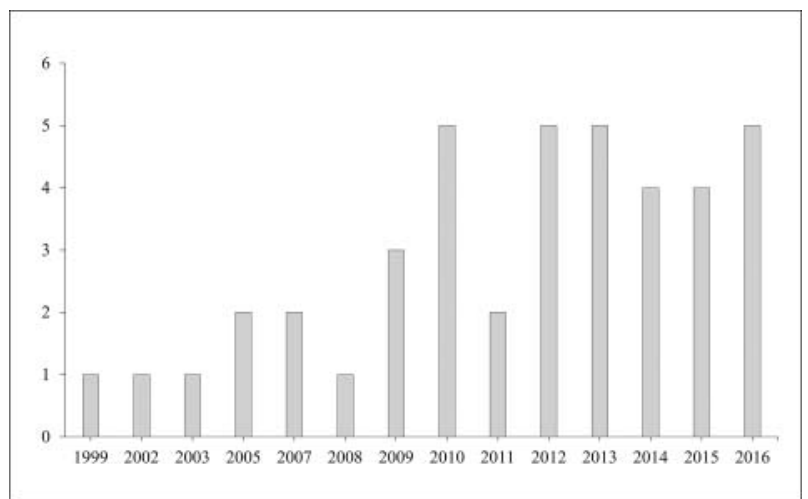

Figure 1. Number of phylogeographic articles published between 1999 and June 2016, referring primarily to plant species occurring in vegetation domains in Brazil.

divergence of lineages of Passiflora contracta associated with the major river basins within the Brazilian Atlantic Forest, including the Doce River.

The Brazilian Atlantic Forest is influenced by several mountain chains in its range (Morellato and Haddad, 2000). Severe restrictions in gene exchange may lead to genetic divergence between populations on different mountains, which would explain the high levels of species diversity in this forest domain (Scarano, 2002). This hypothesis has been confirmed by the few studies of species occurring at high elevations within the Brazilian Atlantic Forest. For example, Lorenz-Lemke et al. (2010)

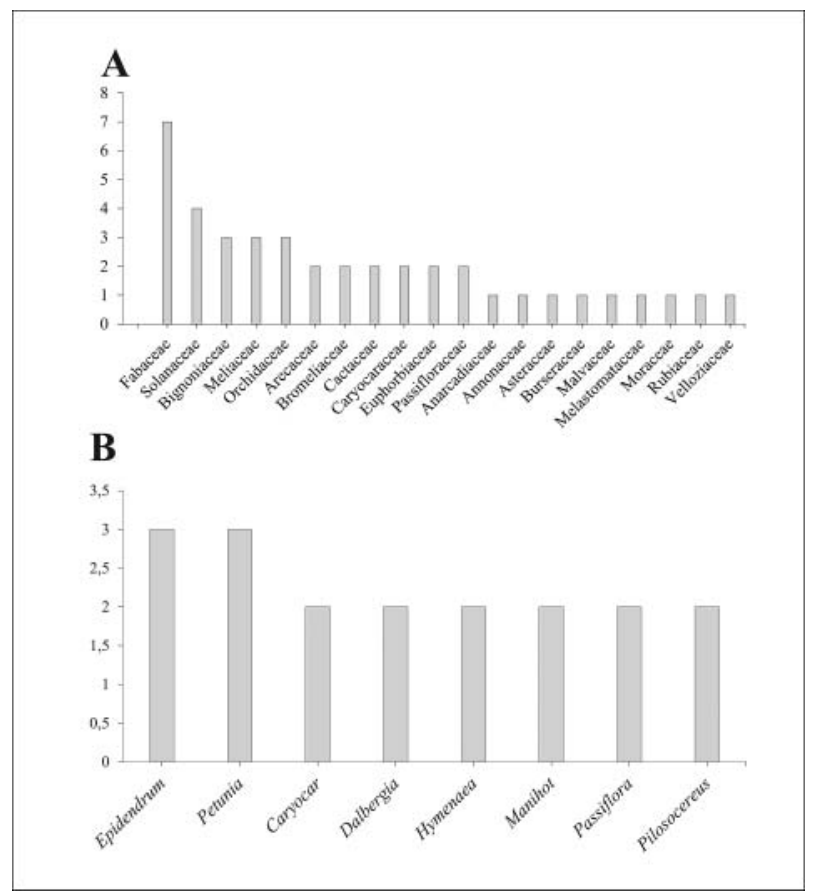

Figure 2. Most frequently investigated plant families $(A)$ and genera that are included more than once $(B)$ in phylogeographic studies of plant species occurring within Brazil. found multiple lineages of Petunia within a species clade restricted to high altitudes. High levels of genetic divergence were found among Pitcairnia lineages endemic to rock outcrops separated by a few kilometers (Palma-Silva et al., 2011). These studies support the view that restrictions of gene exchange in these naturally fragmented environments likely contribute to lineage diversification on mountains. The extent to which the restriction of gene exchange increases the reproductive isolation among these incipient lineages and species, and the role of drift, instead of natural selection, in the fragmented environments, should be addressed by future studies using mountain plants as models. Palma-Silva et al. (2011) reported the permeability of the reproductive barriers between co-occurring Pitcairnia species growing in inselbergs. Extensive levels of haplotype sharing were detected on individual mountains, indicating old hybridization events. Moreover, despite the limited gene flow between conspecific populations, introgression was relatively low and did not affect the cohesion of parental species. In the absence of high levels of gene exchange, selection may play an important role in maintaining species cohesion, particularly in naturally fragmented populations (Palma-Silva et al., 2011; Southcott and Ostevik, 2011).

The Amazonian domain encompasses several countries, but the majority lies in Brazil. Several hypotheses to explain the biogeographical history have been proposed in the Amazon domain (reviewed by Antonelli and Sanmartin, 2011). The effect of soil diversity on levels of plant diversity, tectonic activity, and refuges are considered important drivers of speciation in the Amazonia domain, and were evaluated by phylogeographic studies. However, despite the broad extension and high levels of plant diversity in Amazonia (Forzza et al., 2012), few phylogeographic studies using a lower species level approach have been published (Figure 3A). Fine et al. (2013) investigated two Protium species with different degrees of edaphic specialization: $P$. alvarezianum, an edaphic specialist of white-sand soils distributed throughout the Amazonia domain; and P. subserratum, an edaphic generalist found in different soil types, including white-sand soils. The results confirmed the genetic differentiation of both species, which was partially correlated with the soil types inhabited. The Andean uplift was the most important tectonic event in the recent history of South America. However, a number of other tectonic and geomorphological processes were influenced by the Andean uplift, such as the formation of arches or ridges and changes in the direction and volume of rivers within the Amazon Basin (Marroig and Cerqueira, 1997). Such processes have caused genetic breaks in some species (da Silva and Patton, 1998), and 


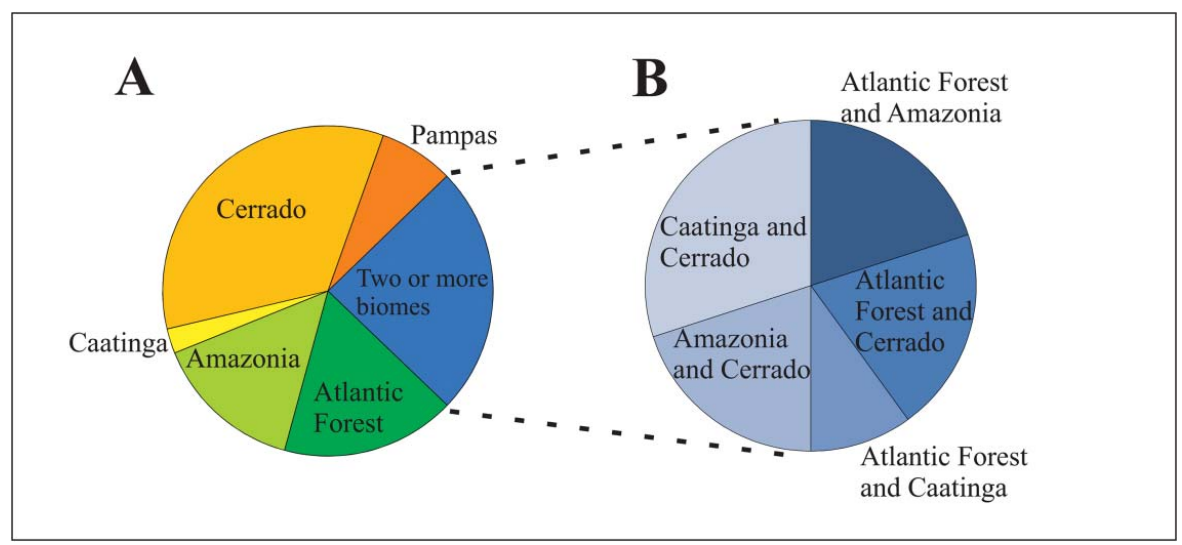

Figure 3. Number of phylogeographic studies using species distributed in single (A) and multiple phylogeographic domains (B).

plant phylogeographic studies have tested some of these hypotheses. For example, Roncal et al. (2015) studied Astrocaryum species and found evidence of allopatric speciation driven by contrasting geological activity in the Fitzcarrald Arch uplift and subsidence of the northern Amazonian foreland basin.

The Refugia Theory is an influential explanation for the origin of species diversity (Bennett and Provan, 2008), including within the Amazonia domain (Hooghiemstra and van der Hammen, 1998). This theory is controversial due to several inconsistencies (reviewed by Rull, 2011). However, the theory has been abandoned in the absence of population-level studies using plants as models. Phylogeographic studies would enable an evaluation of the role of refuge theory in lineage and species diversification in the Amazonia domain, as in other regions (Petit et al., 2003; Liu et al., 2012; Poncet et al., 2013). According to Bennett and Provan (2008), studies of refuges should consider both the size and abundance of populations to detect demographic changes due to glacial/interglacial cycles. Unfortunately, only Lemes et al. (2010) discussed the role of forest refuges in lineage diversification of the tree Swietenia macrophylla. This study detected populations with high levels of differentiation and diversity, which indicates the presence of multiple refuges in the Amazonian basin (Lemes et al., 2010). However, different species may show contrasting patterns of genetic variation due to different pollination and dispersion mechanisms. For example, Dick et al. (2007) detected very low levels of genetic differentiation among populations of Ceiba pentandra, which did not support any past fragmentation of the Amazonia domain. The high level of diversity detected in populations of Jacaranda copaia within the Amazon Basin was interpreted as indicative of a zone of secondary contact between divergent lineages (Scotti-Saintagne et al.,

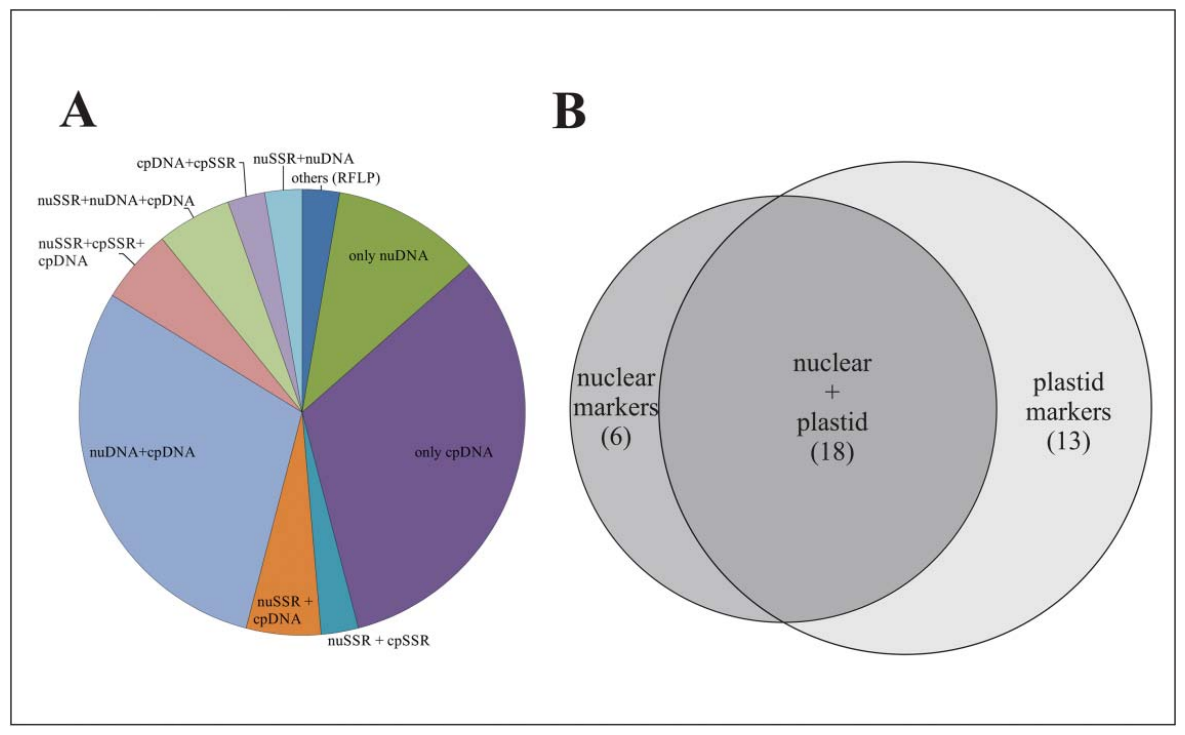

Figure 4. Major molecular markers used in phylogeographic studies of plant species occurring within Brazil (A), and the nuclear and/or organelle origin of markers used in such studies (B). The number of studies is shown in parentheses. 
2013). Studies of multiple co-occurring species have been used as natural replicates to support, or not, the persistence of forest refuges during glacial cycles. Consequently, comparative phylogeographic studies would provide important information about the potential effect of past refuges in lineage diversification, as for previous works on tropical forest trees (Poelchau and Hamrick, 2013).

\section{Phylogeography in seasonal vegetation domains}

The central Brazilian Cerrado and the Caatinga in northeastern Brazil form, together with the Argentinean, Bolivian, and Paraguayan Chaco, the so-called "dry diagonal of open vegetation" of eastern South America (Sarmiento, 1975; Pennington et al., 2006; Werneck, 2011). The Cerrado is a savanna that covers a huge area of central Brazil and has dystrophic soils, a marked seasonality of precipitation, and experiences frequent fires (Pennington et al., 2006). The Caatinga is the largest nucleus of seasonally dry tropical forest in the country (SDTF; Prado and Gibbs, 1993) and typically harbors fertile soils under the drought-prone climate of northeast Brazil (Prado, 2003; Queiroz, 2006). These open vegetation domains are poorly characterized in terms of biogeographical relationships (see review of Werneck, 2011), and the response patterns of organisms from these domains are unclear (Werneck, 2011; Turchetto-Zolet et al., 2013). Phylogeographic studies of plants from the Brazilian open and seasonal domains are biased toward the Cerrado vegetation. Twelve studies focused on this domain, while three focused on species distributed in SDTFs, including the Caatinga (Figure 3A).

The Cerrado is not a uniform savanna, but a mosaic of different physiognomies, including savannas, campos rupestres (rocky fields) and humid formations, such as veredas and gallery forests (Eiten, 1972; Furley and Ratter, 1988). Both geological and paleoclimatic events contributed to the diversification of plant and animal lineages within this domain (Moraes et al., 2009; Prado et al., 2012; Bonatelli et al., 2014). However, studies of plant species from the Cerrado (Table 1) have indicated a preeminent role of the climatic oscillations of the Quaternary on the phylogeographic structure of many species. Although plant community responses to climate are heterogeneous (see above), some diversification patterns have emerged due to the increasing number of species studied, including lineages with distinct ecological requirements.

Tree species in Cerrado show evidence of a recent colonization of the southern Cerrado after a range retraction during the LGM (Collevatti et al., 2003; Ramos et al., 2007; Novaes et al., 2010, 2013; Collevatti et al., 2015; Ribeiro et al., 2016). This pattern is supported by paleopalynological studies (Behling and Lichte, 1997; Behling, 1998; Behling, 2002) and a recent paleodistribution modeling study (Werneck et al., 2012). Nevertheless, retraction with population subdivision in multiple refugia during the LGM has been recorded for a savanna tree species from central Brazil (Collevatti et al., 2012a) and a palm species restricted to wetlands (Lima et al., 2014). Additionally, a single species presented only a slight range retraction, with a large stable area maintained since the LGM (Souza et al., 2016). Higher genetic diversity in the core distribution of diverse plants has also been reported by these phylogeographic studies (Ramos et al., 2007; Novaes et al., 2010, 2013; Ribeiro et al., 2016; Souza et al., 2016).

Variable genetic effects can be determined by differences in natural-history traits among species, especially those in the contrasting formations of the Cerrado domain. Climate fluctuations have affected plants restricted to the campos rupestres formations within the Cerrado in a different manner. Instead of retraction, the evidence suggests range expansion of these plants during glaciations (Collevatti et al., 2009; Barbosa et al., 2012; Collevatti et al., 2012b; Bonatelli et al., 2014). Fossil evidence indicates that the decreasing temperatures and humidity during the glacial period drove a reduction in forest cover and favored the expansion of savanna and grassland vegetation (Salgado-Labouriau et al., 1998; Mayle et al., 2000; Behling and Hooghiemstra, 2001). Such climatic conditions favored range expansion of dry-adapted species to lower altitudes during the LGM. A warmer and wetter climate then resulted in the fragmentation of a broader distribution, which is currently restricted to multiple interglacial microrefugia (see Bonatellii et al., 2014).

Despite these contrasting patterns, studies of the flora of Cerrado have commonly reported a high level of population genetic differentiation (Collevatti et al., 2003; Ramos et al., 2007; Collevatti et al., 2012a, Novaes et al., 2013; Bonatelli et al., 2014). A notable exception is the widely distributed tree species, Dimorphandra mollis, which has lower levels of genetic diversity and genetic differentiation (Souza et al., 2016). Additionally, an eastwest split in genetic structure was observed in both widely distributed tree species (Collevatti et al., 2003; Ramos et al., 2007, 2009; Novaes et al., 2010, 2013; Ribeiro et al., 2016) and plants from rocky fields (Collevati et al., 2009; Bonatelli et al., 2014).

SDTFs are scattered throughout other vegetation types, occurring as enclaves within the Cerrado and Chaco domains, and as isolated nuclei-the largest being located in the Caatinga domain (Prado, 2000; Werneck, 
2011). In fact, the Caatinga domain is one of the least studied Brazilian vegetation region (Turquetto-Zolet et al., 2013), and vegetation shifts in the SDTF during the Pleistocene are unclear (Thomé et al., 2016). The few extant phylogeographic studies that focused on species from SDTFs (Table 1) reported distinct responses to Quaternary climate changes. Two studies of SDTF plant species (i.e., Caetano et al., 2008; Collevatti et al., 2012c) revealed patterns similar to those predicted by the Pleistocene Arc hypothesis (Prado and Gibbs, 1993). According to this hypothesis, SDTFs were widely and continuously distributed during the dry and cold periods of the Pleistocene, and the present-day range of SDTF nuclei is a relic of a wider distribution (Prado and Gibbs, 1993; Pennington et al., 2000). Phylogeographic analyses of Ficus bonijesulapensis (Vieira et al., 2015) and Cedrela fissilis (Garcia et al., 2011), however, showed genetic signatures of a recent expansion (during warmer and wetter periods), which is in accordance with the results of paleodistribution modeling (Werneck et al., 2011) and the dispersal scenarios proposed by Mayle et al. (2004). According to Werneck et al. (2011), the distribution of SDTFs was more fragmented during the LGM than the Holocene, when a southern expansion of this vegetation type occurred. Future research on plant species of these dry and seasonal forests will increase our understanding of the diversification processes of the South American biota.

Seasonal formations also occur in the sub-tropical region of Brazil. The Pampas is one of the largest warm grassland areas globally and occurs in east-central Argentina, Uruguay and the extreme south of Brazil (Fregonezi et al., 2013). This sub-tropical domain is characterized by seasonality in precipitation patterns and soil heterogeneity (Overbeck et al., 2007; Roeschet et al., 2009). Few studies have attempted to investigate the phylogeographic structure of the grassland plant species of Southern Brazil (Figure 3A). Diversification of some typical Pampas vegetation species was influenced by ecological factors to a greater degree than historical factors (forest range shifts or ice-sheet advances) (Fregonezi et al., 2013). For example, Longo et al. (2014) found that morphological variants within the Petunia integrifolia complex may be associated with the variation in soil salinity between mainland and coastal regions. Moreover, an expansion after a size reduction resulted in the establishment of two allopatric groups within this complex, one of them associated with a geologically ancient area and the other in areas under the influence of marine transgressions/regressions. Climatic and sea level changes have also been reported to influence the evolutionary history of Calibrachoa heterophylla and P. integrifolia, herbaceous species from the South Atlantic
Coastal Region (Mader et al., 2013; Ramos-Fregonezi et al., 2015). Both species exhibited a pattern of recent population expansion associated with colonization of coastal regions. There is a clear need to increase the number of studies of specific grassland formations to assess the impact of climate and ecological barriers on speciation in sub-tropical South America.

\section{Phylogeography of species occurring in multiple vegetation domains}

The Amazonia and Brazilian Atlantic Forest domains are separated by a broad corridor of open vegetation physiognomies, comprising the Chaco, the Caatinga, and the Cerrado. This corridor of dry vegetation is an important barrier to species interchange and migration between the two tropical forest domains (Rizzini, 1979; Mori et al., 1981). There is much debate in the literature regarding the biogeographic history of both forest domains. Some authors agree with the view that both Amazonia and the Brazilian Atlantic Forest were more connected in the past, before the LGM (Bigarella et al., 1975; Prance, 1982). During drier periods, gallery forests and seasonal forests may have acted as floristic connections between Amazonia and the Brazilian Atlantic Forest (OliveiraFilho and Ratter, 1995). Alternatively, despite the overall similarities in structure and physiognomy, Amazonia and the Atlantic Forest have a markedly different species composition, which does not support strong biogeographic connections in the past (Oliveira-Filho and Fontes, 2000).

Few plant phylogeographic studies have explored the potential past connection between Amazonia and the Brazilian Atlantic Forest. De Oliveira et al. (2010) reported marked differences between lineages of Carapichea ipecacuanha in Amazonia and the Brazilian Atlantic Forest, suggesting long periods of isolation, rather than past connections. Turcheto-Zolet et al. (2012) reported similar results for the widespread tropical tree species Schizolobium parahyba. Intriguingly, the phylogeographic evidence of past connections between these two forest domains came from studies using animals as models (Costa, 2003; Batalha-Filho et al., 2013; Thomé et al., 2016). Future plant phylogeographic studies should explore the potential existence of past connections between Amazonia and the Brazilian Atlantic Forest, because few empirical data are available. Of special interest are species that occur in both forests (Oliveira-Filho and Fontes, 2000), which should be used as models to evaluate the evolution of these tropical forest domains.

Some phylogeographic studies in Brazil have focused on plant species associated with both mesic and seasonal domains (Figure 3B). Advances in understanding the 
complex shifts among contrasting biomes have resulted from palynological (Behling and Negrelle, 2001; Pessenda et al., 2009) and phylogeographical (Martins et al., 2009; Franco et al., 2012) evidence, but further work is needed. Studies to date have suggested that forest and grassland expansion/fragmentation and dispersal events explain the differentiation among plant populations. Species from the Cerrado-Atlantic Forest were the focus of the phylogeographic studies by Novaes et al. (2010) and Pinheiro et al. (2013). The tree Plathymenia reticulata shows a pattern of recent expansion from the central Cerrado to northeastern Brazil via eastern (Atlantic coast) and western (inland) colonization routes (Novaes et al., 2010). In contrast, recent population contraction events were detected in populations of Epidendrum denticulatum, particularly at the margins of its distribution range (in the Atlantic rainforest), suggesting that it was restricted to multiple refuges during forest expansion events (Pinheiro et al., 2013). Past floristic connections between the Atlantic Forest and Cerrado domains are suggested by this study, because there is no differentiation between $E$. denticulatum populations in such biomes. Such connections are also indicated by the extensive haplotype sharing among populations of $E$. cinnabarinum, a species associated with the Atlantic Forest and Caatinga inselbergs (Pinheiro et al., 2014). This orchid species shows signs of expansion from inland toward dry coastal vegetation zones as a result of longdistance dispersal events. Only two studies sampled populations in Amazonia and Cerrado vegetation (Figure 3B). These studies reported the geographical origins of the cassava (Manihot esculenta) (Olsen et al., 1999), and inferred fragmentation events consistent with post-Pleistocene habitat shifts in the rainforest-Cerrado ecotone (Olsen et al., 2002). We claim here that the historical connection dynamics among Brazilian biomes should take advantage of the emergence of model-based methods of phylogeographic inference. The evidence mentioned above will be confirmed or refuted using other evolutionary scenarios (Collevatti et al., 2012c; Lima et al., 2014).

\section{Final remarks and conclusions}

Plants are long held recognized as models to track climate change over different time scales (Holdridge, 1947). Due to their lack of movement, plant populations show strong changes in distribution and abundance in response to different habitat conditions (Dansereau, 1957; Whitaker, 1975). In this context, plants could be used as models to test the effects of climate change on species distribution under different time scales, from thousands of years to the last century. A detailed record based on fossilized pollen grains has been used for paleovegetation reconstruction (reviewed by Behling, 2002; Ledru et al., 2015). By studying the genetic architecture and lineage history of plant groups present in the fossilized pollen record, phylogeographic studies using plant species may enable testing of the demographic scenarios inferred by paleovegetation reconstructions and by current patterns of genetic diversity. Plants have also provided important insights into the recent and rapid climate changes (Root et al., 2003), and phylogeographic studies are crucial for understanding the effect of such drastic changes on plant populations.

\section{Funding}

Funding for this study was provided by grants from Conselho Nacional de Desenvolvimento Científico e Tecnológico (CPS: CNPq-Universal 475937/2013-9; FP: CNPq-Universal 440367/ 2014-0), Fundação de Amparo à Pesquisa do Estado de São Paulo (CPS: FAPESP-2014/15588-6, BSSL: FAPESP-2014/ 08087-0), and Coordenação de Aperfeiçoamento de Pessoal de Nível Superior (BSSL: CAPES-PhD Fellowship).

\section{References}

Ab'Saber, A. N. 1977. Os domínios morfoclimáticos da América do Sul. Primeira aproximação. Geomorfologia 53: $1-23$.

Antonelli, A., and Sanmartín, I. 2011. Why are there so many plants species in the Neotropics. Taxon 60: 403-414.

Avise, J. C. 2000. Phylogeography: The History and Formation of Species. Harvard University Press, Cambridge, UK.

Avise, J.C, Arnold, J., Ball, R. M., Bermingham, E., Lamb, T., Neigel, J. E., Reeb, C. A., and Saunders, N. C. 1987. Intraspecific phylogeography: the mitochondrial DNA bridge between population genetics and systematics. Annu. Rev. Ecol. Syst. 18: 489-522.

Barbosa, A. R., Fiorini, C. F., Silva-Pereira, V., Mello-Silva, R., and Borba, E. L. 2012. Geographical genetic structuring and phenotypic variation in the Vellozia hirsuta (Velloziaceae) ochlospecies complex. Am. J. Bot. 99: 1477-1488.

Batalha-Filho, H., Fjeldsa, J., Fabre, P. H., and Miyaki, C. Y. 2013. Connections between the Atlantic and the Amazonian forest avifaunas represent distinct historical events. $J$. Ornithol. 154: 41-50.

Beheregaray, L. B. 2008. Twenty years of phylogeography: the state of the field and the challenges for the Southern Hemisphere. Mol. Ecol. 17: 3754-3774.

Behling, H. 1998. Late Quaternary vegetational and climatic changes in Brazil. Rev. Palaeobot. Palynol. 99: 143-156.

Behling, H. 2002. South and southeast Brazilian grasslands during Late Quaternary times: a synthesis. Palaeogeogr. Palaeoclimatol. Palaeoecol. 177: 19-27.

Behling, H., Arz, H. W., Patzold, J., and Gerold, W. 2000. Late Quaternary vegetational and climate dynamics in northeastern Brazil, inferences from marine core GeoB 3104-1. Quat. Sci. Rev. 19: 981-994.

Behling, H., and Hooghiemstra, H. 2000. Neotropical savanna environments in space and time: late quaternary. In: 
Interhemispheric Climate Linkages. pp. 307-323. Markgraf, V., Ed. Academic Press, Oxford, UK.

Behling, H., and Lichte, M. 1997. Evidence of dry and cold climatic conditions at glacial times in tropical southeastern Brazil. Quat. Res. 48: 348-358.

Behling, H., and Negrelle, R. R. B. 2001. Tropical rain forest and climate dynamics of the Atlantic lowland, Southern Brazil, during the Late Quaternary. Quat. Res. 56: 383-389.

Bennett, K. D., and Provan, J. 2008. What do we mean by 'refugia'? Quat. Sci. Rev. 27: 2449-2455.

Bigarella, J. J., Andrade-Lima, D., and Riehs, P. J. 1975. Consideracõees a respeito das mudanças paleoambientais na distribuicão de algumas espécies vegetais e animais no Brasil. Ann. Acad. Bras. Cien. 47: 411-464.

Bonatelli, I. A. S., Perez, M. F., Peterson, A. T., Taylor, N. P., Zappi, D. C., Machado, M. C., Koch, I., Pires, A. H., and Moraes, E. M. 2014. Interglacial microrefugia and diversification of a cactus species complex: phylogeography and palaeodistributional reconstructions for Pilosocereus aurisetus and allies. Mol. Ecol. 23: 3044-3063.

Caetano, S., Prado, D., Pennington, R. T., Beck, S., OliveiraFilho, A., Spichiger, R., and Naciri, Y. 2008. The history of Seasonally Dry Tropical Forests in eastern South America: inferences from the genetic structure of the tree Astronium urundeuva (Anacardiaceae). Mol. Ecol. 17: 3147-3159.

Carnaval, A. C., and Moritz, C. 2008. Historical climate modelling predicts patterns of current biodiversity in the Brazilian Atlantic Forest. J. Biogeogr. 35: 1187-1201.

Cazé, A. L. R., Mäder, G., Nunes, T. S., Queiroz, L. P., de Oliveira, G., Diniz-Filho, J. A., Bonatto, S. L., and Freitas, L. B. 2016. Could refuge theory and rivers acting as barriers explain the genetic variability distribution in the Atlantic Forest? Mol. Phylogenet. Evol. 101: 242-251.

Clapperton, C. M. 1993. Nature of environmental changes in South America at the Last Glacial Maximum. Palaeogeogr. Palaeocl. 101: 189-208.

Collevatti, R. G., Grattapaglia, D., and Hay, J. D. 2003. Evidences for multiple maternal lineages of Caryocar brasiliense populations in the Brazilian Cerrado based on the analysis of chloroplast DNA sequences and microsatellite haplotype variation. Mol. Ecol. 12: 105-115.

Collevatti, R. G., Lima-Ribeiro, M. S., and Souza-Neto, A. C. 2012a. Recovering the demographical history of a Brazilian Cerrado tree species Caryocar brasiliense: coupling ecological niche modeling and coalescent analyses. BMC Evol. Biol. 10: $169-176$.

Collevatti, R. G., de Castro, T. G., Lima, J. S., and Telles, M. P. C. 2012b. Phylogeography of Tibouchina papyrus (Pohl) Toledo (Melastomataceae), an endangered tree species from rocky savannas, suggests bidirectional expansion due to climate cooling in the pleistocene. Ecol. Evol. 2: 1024-1035.

Collevatti, R. G., Rabelo, S. G., and Vieira, R. F. 2009. Phylogeography and disjunct distribution in Lychnophora ericoides (Asteraceae), an endangered cerrado shrub species. Ann. Bot. 104: 655-664.

Collevatti, R. G., Terribile, L. C., Diniz-Filho, J. A., and LimaRibeiro, M. S. 2015. Multi-model inference in comparative phylogeography: an integrative approach based on multiple lines of evidence. Front Genet 6: 31.

Collevatti, R. G., Terribile, L. C., Lima-Ribeiro, M. S., Nabout, J. C., de Oliveira, G., Rangel, T. F., Rabelo, S. G., and DinizFilho, J. A. 2012c. A coupled phylogeographical and species distribution modelling approach recovers the demographical history of a Neotropical seasonally dry forest tree species. Mol. Ecol. 21: 5845-5863.

Collevatti, R. G., Terribile, L. C., Rabelo, S. G., and LimaRibeiro, M. S. 2015. Evolutionary and population genetics relaxed random walk model coupled with ecological niche modeling unravel the dispersal dynamics of a Neotropical savanna tree species in the deeper Quaternary. Front. Plant. Sci. 6: 1-15.

Costa, L. P. 2003. The historical bridge between the Amazon and the Atlantic Forest of Brazil: a study of molecular phylogeography with small mammals. J. Biogeogr. 30: 71-86.

Dansereau, P. M. 1957. Biogeography: An Ecological Perpective. Ronald Press, New York.

Da Silva, M. N. F., and Patton, J. L. 1998. Molecular phylogeography and the evolution and conservation of Amazonian mammals. Mol. Ecol. 7: 475-486.

De Oliveira, L. O., Rossi, A. A. B, Martins, E. R., Batista, F. R., and Silva, R. S. 2010. Molecular phylogeography of Carapichea ipecacuanha, an amphitropical shrub that occurs in the understory of both semideciduous and evergreen forests. Mol. Ecol. 19: 1410-1422.

De Queiroz, A. 2005. The resurrection of oceanic dispersal in historical biogeography. Trends Ecol. Evol. 20: 68-73.

Dick, C. W., Bermingham, E., Lemes, M. R., and Gribel, R. 2007. Extreme long-distance dispersal of the lowland tropical rainforest tree Ceiba pentandra L.(Malvaceae) in Africa and the Neotropics. Mol. Ecol. 16: 3039-3049.

Diniz-Filho, J. A. F., Telles, M. P. C., Bonatto, S., Eizirik, E., Freitas, T. R. O., de Marco, P., Santos, F. R., Solé-Cava, A., And Soares, T. N. 2008. Mapping the evolutionary twilight zone: molecular markers, populations and geography. J. Biogeogr. 35: 753-763.

Eiten, G. 1972. The Cerrado vegetation of Brazil. Bot. Rev. 38: 201-341.

Fine, P. V., Zapata, F., Daly, D. C., Mesones, I., Misiewicz, T. M., Cooper, H. F., and Barbosa, C. E. A. 2013. The importance of environmental heterogeneity and spatial distance in generating phylogeographic structure in edaphic specialist and generalist tree species of Protium (Burseraceae) across the Amazon Basin. J. Biogeogr. 40: 646-661.

Forzza, R. C., Baumgratz, J. F. A., Bicudo, C. E. M., Canhos, D. A., Carvalho, A. A., Coelho, M. A. N., and Lohmann, L. G. 2012. New Brazilian floristic list highlights conservation challenges. BioScience 62: 39-45.

Franco, F. F., and Manfrin, M. H. 2012. Recent demographic history of cactophilic Drosophila species can be related to Quaternary palaeoclimatic changes in South America. J. Biogeogr. 40: 142-154.

Fregonezi, J. N., Turchetto, C., Bonatto, S. L., and Freitas, L. B. 2013. Biogeographical history and diversification of Petunia and Calibrachoa (Solanaceae) in the Neotropical Pampas grassland. Bot. J. Linn. Soc. 171: 140-153.

Furley, P. A., and Ratter, J. A. 1988. Soil resource and plant communities of the central Brazilian Cerrado and their development. J. Biogeogr. 15: 97-108.

Garcia, M. G., Silva, R. S., Carniello, M. A., Veldman, J. W., Rossi, A. A., and de Oliveira, L. O. 2011. Molecular evidence of cryptic speciation, historical range expansion, and recent intraspecific hybridization in the Neotropical seasonal forest tree Cedrela fissilis (Meliaceae). Mol. Phylogenet. Evol. 61: 639-649. 
Haffer, J. 1969. Speciation in Amazonian forest birds. Science 165: 131-137.

Hewitt, G. M. 2001. Speciation, hybrid zones and phylogeography-or seeing genes in space and time. Mol. Ecol. 10: 537549.

Holdridge, L. R. 1947. Determination of world plant formations from simple climatic data. Science 105: 367-368.

Hooghiemstra, H., and van der Hammen, T. 1998. Neogene and Quaternary development of the neotropical rain forest: the forest refugia hypothesis, and a literature overview. Earth-Sci. Rev. 44: 147-183.

Hoorn, C., Wesselingh, F. P., Ter Steege, H., Bermudez, M. A., Mora, A., Sevink, J., Sanmartín, I., Sanchez-Meseguer, A., Anderson, C. L., Figueiredo, J. P., Jaramillo, C., Riff, D., Negri, F. R., Hooghiemstra, H., Lundberg, J., Stadler, T., Särkinen, T., and Antonelli, A. 2010. Amazonia through time: Andean uplift, climate change, landscape evolution, and biodiversity. Science 330: 927-931.

Hughes, C. E., Pennington, R. T., and Antonelli, A. 2013. Neotropical plant evolution: assembling the big picture. Bot. J. Linn. Soc. 171: 1-18.

Ledru, M. P., Montade, V., Blanchard, G., and Hély, C. 2015. Long-term spatial changes in the distribution of the Brazilian Atlantic Forest. Biotropica 48: 159-169.

Leite, Y. L., Costa, L. P., Loss, A. C., Rocha, R. G., BatalhaFilho, H., Bastos, A. C., Quaresma, V. S., Fagundes, V., Paresque, R., Passamani, M., and Pardini, R. 2016. Neotropical forest expansion during the last glacial period challenges refuge hypothesis. Proc. Natl. Acad. Sci. U. S. A. 113: 1008-1013.

Lemes, M. R., Dick, C. W., Navarro, C., Lowe, A., Cavers, S., and Gribel, R. 2010. Chloroplast DNA microsatellites reveal contrasting phylogeographic structure in mahogany (Swietenia macrophylla King, Meliaceae) from Amazonia and Central America. Trop. Plant. Biol. 3: 40-49.

Lima, N. E., Lima-Ribeiro, M. S., Tinoco, C. F., Terribile, R. C., and Collevati, R. G. 2014. Phylogeography and ecological niche modelling, coupled with the fossil pollen record, unravel the demographic history of a Neotropical swamp palm through the Quaternary. J. Biogeogr. 41: 673-686.

Liu, J. Q., Sun, Y. S., Ge, X. J., Gao, L. M., and Qiu, Y. X. 2012. Phylogeographic studies of plants in China: advances in the past and directions in the future. J. Syst. Evol. 50: 267-275.

Lomolino, M. V., Riddle, B. R., Whittaker, R. J., and Brown, J. H. 2010. Biogeography. 4th ed. Sinauer, Sunderland.

Longo, D., Lorenz-Lemke, A. P., Mäder, G., Bonatto, S. L., and Freitas, L. B. 2014. Phylogeography of the Petunia integrifolia complex in southern Brazil. Bot. J. Linn. Soc. 174: 199-213.

Lorenz-Lemke, A. P., Maeder, G., Muschner, V. C., Stehmann, J. R., Bonatto, S. L., Salzano, F. M., and Freitas, L. B. 2006. Diversity and natural hybridization in a highly endemic species of Petunia (Solanaceae): a molecular and ecological analysis. Mol. Ecol. 15: 4487-4497.

Lorenz-Lemke, A. P., Togni, P. D., Mader, G., Kriedt, R. A., Stehmann, J. R., Salzano, F. M., Bonatto, S. L., and Freitas, L. B. 2010. Diversification of plant species in a subtropical region of eastern South American highlands: a phylogeographic perspective on native Petunia (Solanaceae). Mol. Ecol. 19: 5240-5251.

Mäder, G., Fregonezi, J. N., Lorenz-Lemke, A. P., Bonatto, S. L., and Freitas, L. B. 2013. Geological and climatic changes in quaternary shaped the evolutionary history of Calibrachoa heterophylla, an endemic South-Atlantic species of petunia. BMC Evol. Biol. 13: 178.

Marroig, G., and Cerqueira, R. 1997. Plio-Pleistocene South American history and the Amazon lagoon hypothesis: a piece in the puzzle of Amazonian diversification. J. Comp. Biol. 2: 103-119.

Martins, F. M., Templeton, A., Pavan, A. C. O., Kohlbach, B. C., and Morgante, J. S. 2009. Phylogeography of the common vampire bat (Desmodus rotundus): marked population structure, Neotropical Pleistocene vicariance and incongruence between nuclear and mtDNA markers. BMC Evol. Biol. 9: 294

Mayle, F., Beerling, D., Gosling, W., and Bush, M. 2004. Responses of Amazonian ecosystems to climatic and atmospheric carbon dioxide changes since the last maximum. Philos. Trans. R. Soc. Lond. 359: 499-514.

Mayle, F. E., Burbridge, R., and Killeen, T. J. 2000. Millennialscale dynamics of southern Amazonian rain forests. Science 290: 2291-2294.

Moraes, E. M., Yotoko, K. S. C., Manfrin, M. H., Solferini, V. N., and Sene, F. M. 2009. Phylogeography of the cactophilic species Drosophila gouveai: demographic events and divergence timing in dry vegetation enclaves in eastern Brazil. $J$ Biogeogr 36: 2136-2147.

Morellato, L. P. C., and Haddad, C. F. 2000. Introduction: The Brazilian Atlantic Forest. Biotropica 32: 786-792.

Mori, S. A., Boom, B. M., and Prance, G. T. 1981. Distribution patterns and conservation of eastern Brazilian coastal forest tree species. Brittonia 33: 233-245.

Novaes, R. M. L., Lemos-Filho, J. P., Ribeiro, R. A., and Lovato, M. B. 2010. Phylogeography of Plathymenia reticulata (Leguminosae) reveals patterns of recent range expansion towards northeastern Brazil and southern Cerrados in Eastern Tropical South America. Mol. Ecol. 19: 985-998.

Novaes, R. M. L, Ribeiro, R. A., Lemos-Filho, J. P., and Lovato, M. B. 2013. Concordance between phylogeographical and biogeographical patterns in the Brazilian Cerrado: diversification of the endemic tree Dalbergia miscolobium (Fabaceae). PLoS One 8: e82198-e82198.

Oliveira-Filho, A. T., and Fontes, M. A. L. 2000. Patterns of floristic differentiation among Atlantic Forests in southeastern Brazil and the influence of climate. Biotropica 32: 793810.

Oliveira-Filho, A. T., and Ratter, J. A. 1995. A study of the origin of central Brazilian forests by the analysis of plant species distribution patterns. Edinburgh J. Bot. 52: 141-194.

Olsen, K. M. 2002. Population history of Manihot esculenta (Euphorbiaceae) inferred from nuclear DNA sequences. Mol. Ecol. 11: 901-911.

Olsen, K. M., and Schaal, B. A. 1999. Evidence on the origin of cassava: phylogeography of Manihot esculenta. Proc. Natl. Acad. Sci. U. S. A. 96: 5586-5591.

Overbeck, G. E., Müller, S. C., Fidelis, A., Pfadenhauer, J., Pillar, V. D., Blanco, C. C., Boldrini, I. I., Both, R., and Forneck, E. D. 2007. Brazil's neglected biome: The South Brazilian Campos. Perspect. Plant. Ecol. Evol. Syst. 9: 101116.

Palma-Silva, C., Lexer, C., Paggi, G. M., Barbará, T., Bered, F., and Bodanese-Zanettini, M. H. 2009. Range-wide patterns of nuclear and chloroplast DNA diversity in Vriesea gigantea (Bromeliaceae), a neotropical forest species. Heredity 103: 503-512. 
Palma-Silva, C., Wendt, T., Pinheiro, F., Barbará, T., Fay, M. F., Cozzolino, S., and Lexer, C. 2011. Sympatric bromeliad species (Pitcairnia spp.) facilitate tests of mechanisms involved in species cohesion and reproductive isolation in Neotropical inselbergs. Mol. Ecol. 20: 3185-3201.

Pennington, R. T., Lewis, G. P., and Ratter, J. A. 2006. Neotropical Savannas and Seasonally Dry Forests: Plant Diversity, Biogeography and Conservation. CRC Press Taylor \& Francis Group, Boca Raton/London/New York.

Pennington, R. T., Prado, D. E., and Pendry, C. A. 2000. Neotropical seasonally dry forests and Quaternary vegetation changes. J. Biogeogr. 27: 261-273.

Pessenda, L. C. R., Oliveira, P. E., Mofatto, M., Medeiro, V. B., Garcia, R. J. F., Aravena, R., Bendassoli, J. A., Leite, A. Z., Saad, A. R., and Etchebehere, M. L. 2009. The evolution of a tropical rainforest/grassland mosaic in southeastern Brazil since 28,000 14C yr BP based on carbon isotopes and pollen records. Quat. Res. 71: 437-452.

Petit, R. J., Aguinagalde, I., de Beaulieu, J. L., Bittkau, C., Brewer, S., Cheddadi, R., and Mohanty, A. 2003. Glacial refugia: hotspots but not melting pots of genetic diversity. Science 300: 1563-1565.

Pinheiro, F., Cozzolino, S., de Barros, F., Gouveia, T. M. Z. M, Suzuki, R. M., Fay, M. F., and Palma-Silva, C. 2013. Phylogeographic structure and outbreeding depression reveal early stages of reproductive isolation in the neotropical orchid. Epidendrum denticulatum. Evolution 67: 20242039.

Pinheiro, F., Cozzolino, S., Draper, D., de Barros, F., Félix, L. P., Fay, M. F., and Palma-Silva, C. 2014. Rock outcrop orchids reveal the genetic connectivity and diversity of inselbergs of northeastern Brazil. BMC Evol. Biol. 14: 49.

Poelchau, M. F., and Hamrick, J. L. 2013. Comparative phylogeography of three common Neotropical tree species. J. Biogeogr. 40: 618-631.

Poncet, V., Munoz, F., Munzinger, J., Pillon, Y., Gomez, C., Couderc, M., and Kochko, A. 2013. Phylogeography and niche modelling of the relict plant Amborella trichopoda (Amborellaceae) reveal multiple Pleistocene refugia in New Caledonia. Mol. Ecol. 22: 6163-6178.

Prado, D. E. 2000. Seasonally Dry Forests of Tropical South America: from forgotten ecosystems to a new phytogeographic unit. Edinburg J. Bot. 57: 437-461.

Prado, D. E. 2003. As Caatingas da América do Sul. In: Ecologia e Conservação da Caatinga. pp. 3-73. Leal, I. R., Tabarelli, M., Silva, J. M. C., Eds. Editora Universitária UFPE, Recife.

Prado, D. E., and Gibbs, P. E. 1993. Patterns of species distributions in the dry seasonal forests of South America. Ann. Missouri. Bot. Gard. 80: 902-927.

Prado, C. P. A., Haddad, C. F. B., and Zamudio, K. R. 2012. Cryptic lineages and Pleistocene population expansion in a Brazilian Cerrado frog. Mol Ecol 21: 921-941.

Prance, G. T. 1982. A review of the phytogeographic evidences for Pleistocene climate changes in the Neotropics. Ann. Mo. Bot. Gard. 69: 594-624.

Queiroz, L. P. 2006. The Brazilian Caatinga: phytogeographical patterns inferred from distribution data of the Leguminosae. In: Neotropical Savannas and Seasonally Dry Forests: Plant Diversity, Biogeography and Conservation. pp. 113149. Pennington, R. T., Lewis, G. P., and Ratter, J. A., Eds. Taylor \& Francis, Boca Raton, FL.
Ramos, A. C. S., Lemos-Filho, J. P., and Lovato, M. B. 2009. Phylogeographical structure of the neotropical forest tree Hymenaea courbaril (Leguminosae: Caesalpinioideae) and its relationship with the vicariant Hymenaea stigonocarpa from Cerrado. J. Hered. 100: 206-216.

Ramos, A. C. S., Lemos-Filho, J. P., Ribeiro, R. A., Santos, F. R., and Lovato, M. B. 2007. Phylogeography of the tree Hymenaea stigonocarpa (Fabaceae: Caesalpinioideae) and the influence of quaternary climate changes in the Brazilian cerrado. Ann. Bot. 100: 1219-1228.

Ramos-Fregonezi, A. M., Fregonezi, J. N., Cybis, G. B., Fagundes, N. J. R., Bonatto, S. L., and Freitas, L. B. 2015. Were sea level changes during the Pleistocene in the South Atlantic Coastal Plain a driver of speciation in Petunia (Solanaceae)? BMC Evol. Biol. 15: 92.

Ribeiro, P. C., Lemos-Filho, J. P., Buzatti, R. S. O., Lovato, M. B., and Heuertz, M. 2016. Species-specific phylogeographical patterns and Pleistocene east-west divergence in Annona (Annonaceae) in the Brazilian Cerrado. Bot. J. Linn. Soc. 181: 21-36.

Ribeiro, R. A., Lemos-Filho, J. P., Ramos, A. C. S., and Lovato, M. B. 2011. Phylogeography of the endangered rosewood Dalbergia nigra (Fabaceae): insights into the evolutionary history and conservation of the Brazilian Atlantic Forest. Heredity 106: 46-57.

Rizzini, C. T. 1979. Tratado de fitogeografia do Brasil. Editora Universidade de São Paulo, São Paulo.

Roesch, L. F. W., Vieira, F. C. B., Pereira, V. A., Schüneman, A. L., Teixeira, I. F., Senna, A. J. T., and Stefenon, V. M. 2009. The Brazilian Pampa: a fragile biome. Diversity 1: 182-198.

Roncal, J., Couderc, M., Baby, P., Kahn, F., Millán, B., Meerow, A. W., Pintaud, J. C. 2015. Palm diversification in two geologically contrasting regions of western Amazonia. J. Biogeogr. 42: 1503-1513.

Root, T. L., Price, J. T., Hall, K. R., Schneider, S. H., Rosenzweig, C., and Pounds, J. A. 2003. Fingerprints of global warming on wild animals and plants. Nature 421: 57-60.

Rull, V. 2011. Neotropical biodiversity: timing and potential drivers. Trends. Ecol. Evol. 26: 508-513.

Salgado-Labouriau, M. L., Barberi, M., Ferraz-Vicentini, K. R., and Parizzi, M. G. 1998. A dry climatic event during the Late Quaternary of tropical Brazil. Rev. Palaeobot. Palynol. 9: 115-129.

Sanmartín, I. 2012. Historical biogeography: evolution in time and space. Evol. Educ. Outreach. 5: 555-568.

Sarmiento, G. 1975. The dry plant formations of South America and their floristic connections. J. Biogeogr. 2: 233-251.

Scarano, F. R. 2002. Structure, function and floristic relationships of plant communities in stressful habitats marginal to the Brazilian Atlantic rainforest. Ann. Bot. 90: 517-524.

Scopece, G., Lexer, C., Widmer, A., and Cozzolino, S. 2010. Polymorphism of postmating reproductive isolation within plant species. Taxon 59: 1367-1374.

Soltis, D. E., Moore, M. J., Burleigh, G., and Soltis, P. S. 2009. Molecular markers and concepts of plant evolutionary relationships: progress, promise, and future prospects. Crit. Rev. Plant. Sci. 28: 1-15.

Southcott, L., and Ostevik, K. L. 2011. Bromeliad population genetics reveals species cohesion against the odds. Mol. Ecol. 20: 3081-3083.

Souza, H. A. V., Collevatti, R. G., Lima-Ribeiro, M. S., LemosFilho, J. P., and Lovato, M. B. 2016. A large historical refugium explains spatial patterns of genetic diversity in a 
Neotropical savanna tree species. Ann. Bot. doi: 10.1093/ aob/mcw096

Teixeira, M. C., Mäder, G., Silva-Arias, G. A., Bonatto, S. L., and Freitas, L. B. 2016. Effects of past climate on Passiflora actinia (Passifloraceae) populations and insights into future species management in the Brazilian Atlantic Forest. Bot. J. Linn. Soc. 180: 348-364.

Thomé, M. T. C., Sequeira, F., Brusquetti, F., Carstens, B. C., Haddad, C. F. B., Rodrigues, M. T., and Alexandrino, J. 2016. Recurrent connections between Amazon and Atlantic forests shaped diversity in Caatinga four-eyed frogs. J. Biogeogr. 43: 1045-1056.

Turchetto-Zolet, A. C., Cruz, F., Vendramin, G. G., Simon, M. F., Salgueiro, F., Margis-Pinheiro, M., and Margis, R. 2012. Large-scale phylogeography of the disjunct Neotropical tree species Schizolobium parahyba (Fabaceae-Caesalpinioideae). Mol. Phylogenet. Evol. 65: 174-182.

Turchetto-Zolet, A. C., Pinheiro, F., Salgueiro, F., and PalmaSilva, C. 2013. Phylogeographical patterns shed light on evolutionary process in South America. Mol. Ecol. 22: 1193-1213.
Vieira, F. D. A., Novaes, R. M. L., Fajardo, C. G., Santos, R. M., Almeida, H. S., Carvalho, D., and Lovato, M. B. 2015. Holocene southward expansion in seasonally dry tropical forests in South America: phylogeography of Ficus bonijesulapensis (Moraceae). Bot. J. Linn. Soc. 177: 189-201.

Werneck, F. P. 2011. The diversification of eastern South American open vegetation biomes: historical biogeography and perspectives. Quat. Sci. Rev. 30: 1630-1648.

Werneck, F. P., Costa, G. C., Colli, G. R., Prado, D. E., and Jr Sites, J. W. 2011. Revisiting the seasonally dry tropical forests historical distribution: new insights based on palaeodistribution modelling and palynological evidence. Glob. Ecol. Biogeogr. 20: 272-288.

Werneck, F. P., Nogueira, C., Colli, G. R., Sites, J. W., and Costa, G. C. 2012. Climatic stability in the Brazilian Cerrado: implications for biogeographical connections of South American savannas, species richness and conservation in a biodiversity hotspot. J. Biogeogr. 39: 1695-1706.

Whittaker, R. H. 1975. Communities and Ecosystems. 2nd ed. Macmillan, New York. 